Document downloaded from:

http://hdl.handle.net/10251/49869

This paper must be cited as:

Montañés Sanjuan, MT.; Sánchez Tovar, R.; Roux, MSB. (2014). The effectiveness of the stabilization/solidification process on the leachability and toxicity of the tannery sludge chromium. Journal of Environmental Management. 143:71-79. doi:10.1016/j.jenvman.2014.04.026.

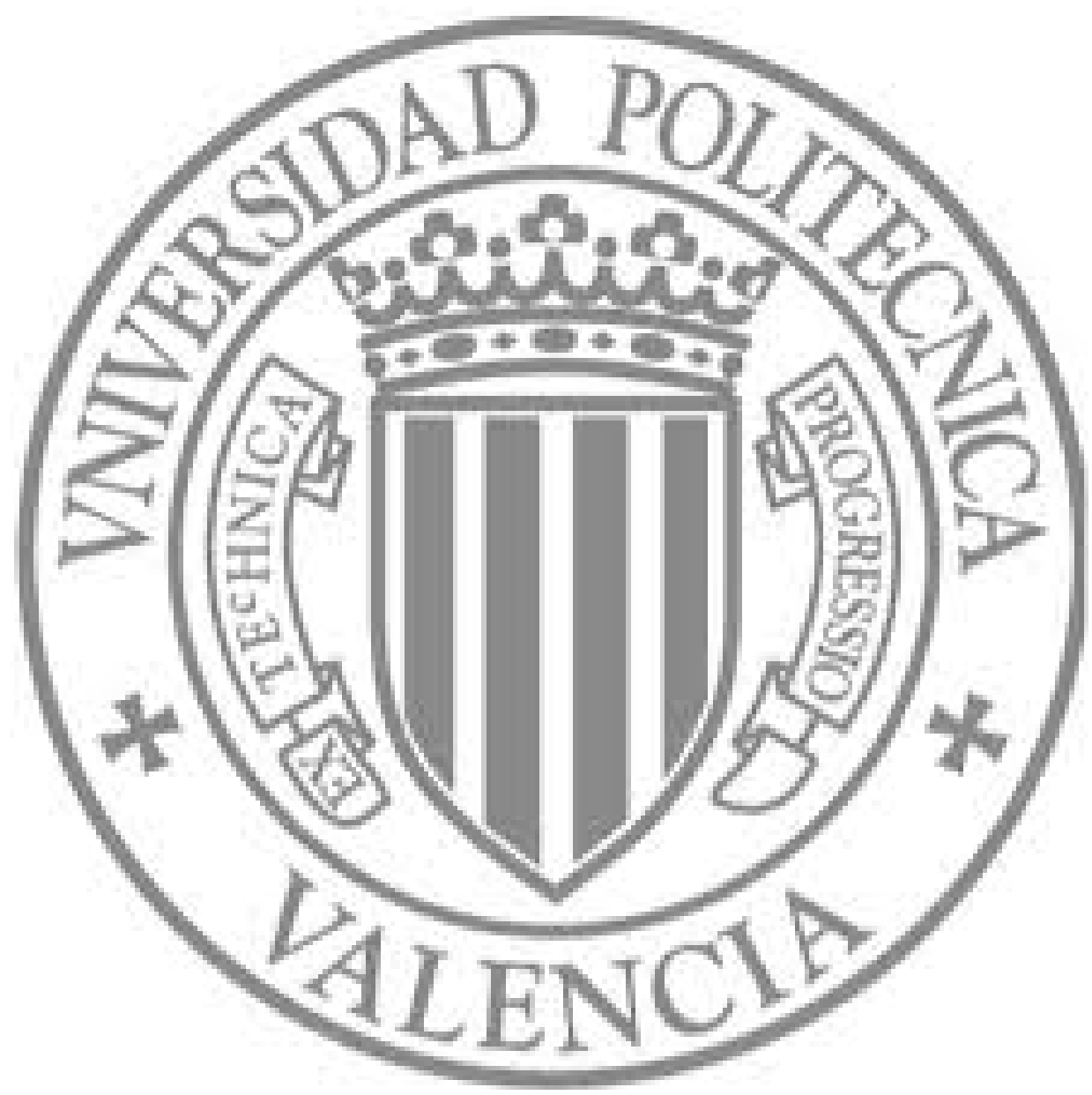

The final publication is available at

http://dx.doi.org/10.1016/j.jenvman.2014.04.026

Copyright Elsevier 


\title{
THE EFFECTIVENESS OF THE STABILIZATION/SOLIDIFICATION PROCESS ON THE LEACHABILITY AND TOXICITY OF THE TANNERY SLUDGE CHROMIUM
}

\author{
M.T. Montañés ", R. Sánchez-Tovar, M.S. Roux. \\ Ingeniería Electroquímica y Corrosión. Departamento de Ingeniería Química y Nuclear. \\ Universitat Politècnica de València (Polytechnic University of Valencia) \\ Camino de Vera s/n, 46022 Valencia, Spain \\ Tel. +34963879637; Fax. +34963877639 "tmontane@iqn.upv.es
}

\begin{abstract}
A stabilization/solidification (S/S) process by using cement was applied to tannery sludge in order to find a safer way of landfilling this waste. The effects of three parameters on the process effectiveness were analysed in terms of leachate toxicity and chromium retention (\%). The parameters studied were the relative amount of added water (30-50 wt.\%), cement (10-60 wt.\% in the solid components), and the use of three different types of cement (clinker with additions of limestone, with additions of limestone and fly ashes, and with additions of pozzolans). Statistical analysis performed by variance analysis and categorical multifactorial tests reveals that all the studied parameters significantly influence the effectiveness of the process. Results showed that chromium retention decreases as the relative amount of cement and water increases, probably due to additional chromium provided by cement and increased in the porosity of the mixtures. Leachate toxicity showed the same minimum value for mixtures with $30 \%$ or $40 \%$ cement, depending on the type of cement, showing that clinker is the main material responsible for the process effectiveness, and additives (pozzolans or fly ashes)
\end{abstract}


do not improve it. The volume increase is lower as less sludge is replaced by cement and the relative amount of water decreases, and for the cement without additions of fly ashes or pozzolans. Therefore, the latter seems to be the most appropriate cement in spite of being more expensive. This is due to the fact that the minimum toxicity value is achieved with a lower amount of cement; and moreover, the volume increase in the mixtures is lower, minimizing the disposal cost to a landfill.

Keywords: tannery sludge, stabilization/solidification, chromium, toxicity.

\section{Introduction}

The European Union is the world's largest supplier of leather in the international marketplace. Italy is the major leather supplying country in Europe. It accounts for 15\% of the world's cattle and calf leather production and $65 \%$ of EU production. Spain ranks second and (with France, Germany and UK) accounts for most of the balance in the European leather industry (European Commission, 2003a).

The tanning industry is a potentially pollution-intensive industry. The tannery operation consists of converting the raw hide or skin into leather, which can be used in the manufacture of a wide range of products. Tanning is the process fundamental stage, which provides the stability of leather. An $80-90 \%$ of tanneries use chromium (III) salts in their tanning processes, in particular, chromium sulphate (Houshyar et al., 2012; Kiliç, 2011; Shakir et al., 2012; Torras et al., 2012). Hides that have been tanned with chromium salts have a good mechanical resistance, an extraordinary dying suitability and a better hydrothermal resistance in comparison with hides treated with plant 
substances (Krishnamoorthy et al., 2012; Nashy et al., 2012; Piccin et al., 2012; Sundarapandiyan et al., 2011). Chromium salts have also a high rate of penetration into the interfibrillar spaces of the skin, providing a saving in terms of production time and a better control of the process (Basegio et al., 2009; Cassano et al., 1996). However, the chromium toxicity is one of the most debated issues between the tanning industry and the authorities (European Commission, 2003a).

Between 30-50\% chromium applied in conventional chromium tanneries is lost with the wastewater. Tanneries in Europe usually discharge their wastewater effluents to large wastewater treatment plants. Most tanneries discharging directly into sewer have some form of on-site effluent treatment system which usually involves the chromium precipitation. In this way, the sludge from the effluent treatment plant is approximately $500 \mathrm{~kg}$ (approximately 40\% dry matter content) per tonne of raw hide (bovine salted hides) treated (Erdem and Özverdi, 2008; European Commission, 2003a).

The wastes listing in the European Waste List in the 0401 group, are mainly from the leather and fur industry; consequently, the code 040106 is described as sludges, in particular from on-site effluent treatment containing chromium (European Commission, 2000). These sludges are not included in the European Hazardous Waste List because do not possess the necessary characteristics to be classified as a hazardous waste according to European Commission. However, The United States of America environmental regulations consider chromium and chromium compounds as hazardous constituents in waste materials (US Environmental Protection Agency, 1998). 
Moreover, the German environmental regulations consider hazardous all wastes from the leather and hide processing (Basegio et al., 2009; Bundesrat, 1990).

One of the main environmental impacts of metal-containing sludges is the leaching of heavy metals to surface and ground water. Leaching tests therefore play a major role in the assessment of the classification, the compatibility of use and the treatment according to the environmental impact assessment of disposal or technical-economical possibilities of reuse. Spanish environmental regulations specify the DIN 38414-S4 compliance test (Spanish Government, 2002); and moreover, European regulations establish the criteria for the acceptance of waste at landfills (European Commission, 2003b).

S/S technologies use binders and additives to reduce the mobility and toxicity of the pollutants contained in wastes, and generate a final product that can be reused or deposited in landfills (Kogbara et al., 2013; Li et al., 2014; Navarro-Blasco et al., 2013; Silva et al., 2007; Ucaroglu and Talinli, 2012; Yoon et al., 2010). Stabilization refers to techniques that chemically reduce the hazard potential of a waste by converting the contaminants into less soluble, mobile, or toxic forms, while solidification refers to techniques that encapsulate the waste, forming a solid material, and does not necessarily involve a chemical interaction between the contaminants and the solidifying additives. The product of solidification may be a monolithic block, a clay-like material, granular particulates, or some other physical form commonly considered solid. Technology involving the $\mathrm{S} / \mathrm{S}$ processes is currently being used to treat a wide variety of wastes from different industries, such as sludge from the tannery and from the wastewater 
treatment plants of electroplating and metal finishing industries (Aydin and Aydin, 2014; Erden and Özverdi, 2008; Silva et al., 2007). These wastes usually contain contaminants such as heavy metals, organics and soluble salts (Navarro-Blasco et al., 2013; Yoon et al., 2010; Silva et al., 2007).

$\mathrm{S} / \mathrm{S}$ processes are classified in terms of the binder used to encapsulate the waste, and can be divided into organic and inorganic-binder processes (Conner, 1990). The organic binders are asphalts or polymers such as polyesters, epoxy resins and polyolefins, whereas the inorganic binders are usually cement (others are lime, gypsum or zeolites).

S/S by cementation processes is used for wastes containing heavy metals. These processes, based on reactions with pozzolans or cement, are generally relatively inexpensive and easy to use (Rodríguez and Irabien, 1999). Although the S/S technology has been studied in previous works with wastes containing heavy metals, as an example with lead, arsenic, chromium, cadmium and zinc (Li et al., 2014; Peysson et al., 2005), and there are some literature in relation to the S/S of tanning industry wastes using cement (Swarnalatha et al., 2008), these studies focused on the leaching tests and did not evaluate the toxicity of the obtained solid product.

The aim of this research is to optimize the S/S process of tannery sludge by using cement for its final disposal in landfills. The effectiveness of the process is analysed in terms of leachate toxicity and percentage chromium retention: relative amount of water, cement and tannery sludge added to the mixtures, and the use of three different types of cement. Statistical analysis of the results is carried out to define the relevance of each 
experimental parameter on the S/S process. In this way, analysis of variance (ANOVA) is performed to prove if changes in water and cement contents are statistically significant on the analysed effectiveness variables. Additionally, categorical multifactorial experimental design is conducted to evaluate the interactions between the content and the type of cement on the S/S procedure.

\section{Experimental procedure}

\subsection{Sludge characterization}

Sludges were collected in the form of filter cakes from the water treatment plant of a conventional chromium tanning facility, located in Valencia (Spain). According to the material data sheet supplied by the tanning facility, these sludges are primarily organic wastes (41 wt.\% of total solids are volatile) and they contain heavy metals, such as zinc (51 mg/kg dry matter), cadmium (< $0.5 \mathrm{mg} / \mathrm{kg}$ dry matter), copper $(182 \mathrm{mg} / \mathrm{kg}$ dry matter), nickel (80 mg/kg dry matter), lead (112 mg/kg dry matter), and chromium (7750 $\mathrm{mg} / \mathrm{kg}$ dry matter). From the aforesaid data chromium is the major pollutant and therefore, the degree of chromium toxicity is critical.

Moisture, density, chromium content and leachate characteristics were determined for the selected sludge. Table 1 shows the mean values obtained after carrying out the analysis in triplicate. Moisture was determined in accordance with the EN 14346:2006 compliance test (EN 14346, 2006). The density value was determined to find the initial volume of the sludge in order to calculate the increase produced when it was mixed with cement. Density was obtained by introducing an amount of sludge in water and measuring the volume of water displaced. The chromium content and the leachate 
characteristics are the necessary parameters to calculate the effectiveness of the S/S process. In order to obtain the chromium content, an acid-digestion of the sludge using $0.5 \mathrm{M}$ sulfuric acid was performed prior to elementary analysis. The leaching test and the analytical techniques used are described below.

\section{Table 1}

\subsection{Types of cement}

Three different commercial cements based on Portland cement were used to perform $\mathrm{S} / \mathrm{S}$ of the tanning sludge by a cementation process. Table 2 shows the average composition of the three cements supplied by the manufacturer.

\section{Table 2}

CEM II/A-L 42.5 $\mathrm{R}$ is the type of cement most commonly used in Spain to prepare concretes and mortars ordinary. On the other hand, additives can be used to initiate, catalyze or, in general, improve the characteristics of agglutinating agents and the agglutinating reactions between reagents and wastes; the most used additives with inorganic binders are pozzolans, fly ashes, silicates and active carbon (Rodríguez and Irabien, 1999). Thus, two commercial Portland cements with fly ashes (CEM II/B-M (V-LL) $32.5 \mathrm{~N}$ ) and natural pozzolans (CEM II/B-P $32.5 \mathrm{~N}$ ) were also used. According to the manufacturer's materials data sheet, the added fly ashes were obtained from coalburning power plants, whereas natural pozzolans were obtained from quarries; 
additional components (Table 2) are basically limestone, although they could also contain traces of heavy metals, such as lead, zinc or chromium.

Chromium content and leachate characteristics were determined for the three cements in order to verify if they could influence the toxicity levels of the resulting mixtures. An acid-digestion of the cements using $0.5 \mathrm{M}$ sulfuric acid was performed prior to elementary analysis. The leaching test and the analytical techniques used are described below. Table 3 shows the mean values obtained after carrying out the analysis in triplicate. Chromium contents $(\mathrm{mg} / \mathrm{kg}$ dry matter) are in agreement with the values obtained by Ogunbileje (Ogunbileje et al., 2013) and they are one order of magnitude less than the tannery sludge (Table 1). However, toxicity levels (TU) of the three cements are similar to the sludge (Table 1). This fact could be attributed to the presence of other metals that are usually present in cements (Ogunbileje et al., 2013).

\section{Table 3}

\subsection{Mixtures}

Table 4 shows the composition of the mixtures. The experimental work was designed considering the following parameters:

- Type of cement: clinker with additions of limestone (M1), clinker with additions of limestone and fly ashes (M2) and clinker with additions of pozzolans (M3).

- Relative amount of water added to the mixture, ranging from 30 to $50 \mathrm{wt} . \%$

- Relative amount of sludge in the solid components of the mixture, ranging from 40 to $90 \mathrm{wt} . \%$, and balanced with cement. 


\section{Table 4}

Mixing was carried out on a rotary mixer with a capacity from 3 to $5 \mathrm{~kg}$ per charge. After mixing, each mixture was placed in a tray of $30 \mathrm{~cm}$ long, $24 \mathrm{~cm}$ wide and $6 \mathrm{~cm}$ high. They were then weighed and left for 28 days under room temperature and humidity conditions.

After 28 days of curing, the mixtures were weighed again. Density values were then calculated to find the final volume of the cured mixtures by means of measuring the water volume displaced by an amount of cured mixture. The leachate characteristics were also determined for all the cured mixtures.

\subsection{Leaching test}

Leaching tests were performed in triplicate to evaluate the chromium retention capacity of the original sludge and cements, and also of the mixtures after 28 days of curing. Leaching was performed in accordance with the Spanish regulations on the characterization of hazardous wastes (Spanish Government, 1989). The procedure consisted of subjecting mixtures (or the original sludge or cements) to acetic acid solution in a slowly rotating container.

A pulverized mixture of particle size less than $10 \mathrm{~mm}$ was weighed and mixed with distilled water, to a solid mixture/liquid ratio equal to $1 / 16$ by weight. The $\mathrm{pH}$ of the solution was checked after 15, 30 and 60 minutes intervals of mixing and adjusted to 
$5 \pm 0.2$ by adding $0.5 \mathrm{M}$ acetic acid (the maximum added volume is $4 \mathrm{ml}$ of $0.5 \mathrm{M}$ acetic acid per gram of solid mixture). After $24 \mathrm{~h}$ under permanent stirring at room temperature, more distilled water was added according to the following equation:

$$
V=4 \cdot W-A
$$

where $V$ is the volume of added distilled water, in $\mathrm{ml} ; W$ is the mass of the solid mixture, in $\mathrm{g}$; and $A$ is the total volume of added acetic acid, in ml (Alunno-Rossetti, 2002; Spanish Government, 1989; Viñals et al, 2002). The final value of the solid mixture/liquid ratio was equal to $1 / 20$ by weight. After adding the calculated volume of water, the extract was sieved through a 0.45 micron filter before analysis.

\subsection{Analytical technique}

Chromium content and toxicity were determined in order to characterize the leachate. The chemical and ecotoxicological tests complement each other in order to classify the wastes as hazardous and to evaluate the effectiveness of the S/S treatment (Seco et al, 2003).

The concentration of chromium in the leachate, so as in the solution obtained by aciddigestion of the original sludge and cements, was determined by means of a PerkinElmer model AAnalyst 100 atomic absorption spectrophotometer (PerkinElmer Inc., USA) using a chromium hollow cathode lamp and an air-acetylene flame. Instrumental parameters were adjusted according to the manufacturer's recommendations: $428.9 \mathrm{~nm}$ wavelength, $0.2 \mathrm{~nm}$ spectral bandwidth and an operating lamp current of $20 \mathrm{~mA}$. 
The toxicity of the leachate was determined using a Microtox model M-500 Analyser (Strategic Diagnostics Inc., USA), which can detect toxicities by the changes in the level of luminescence from the marine bioluminescent bacterium, Vibrio fischeri. This bacterium was used because it is the most sensitive across a wide range of chemicals. Assays were carried out at $15{ }^{\circ} \mathrm{C}$, salinity level of $2 \% \mathrm{NaCl}$ and $\mathrm{pH}$ range of 6-8. Leachate samples were diluted according to the manufacturer's instructions and the inhibitory concentrations, $\mathrm{EC}_{50}\left(15 \mathrm{~min}, 15^{\circ} \mathrm{C}\right)$, were estimated by the MicrotoxOmni software supplied by the manufacturer. Hence, toxicity can be expressed as $n$-TU (toxicity units), where $n$ is the number of times that leachate must be diluted to inhibit the luminescence of $50 \%$ of the luminescent microorganisms at $15^{\circ} \mathrm{C}$ during $15 \mathrm{~min}$.

\subsection{Statistical analysis}

Data were subjected to variance analysis (one-way ANOVA), using least significant differences (LSD) test with a 95\% confidence interval for differences between means (Statgraphics Plus 5.1, Manugistics, Inc., Rockville, MA, USA). This analysis was carried out in a typical Portland cement in order to determine if changes in the cement content were statistically significant on the studied variables (leached chromium, toxicity and volume increase). Then, the influence of the type of cement was carried out using the most appropriate percentage of cement from an environmental point of view. In this way, a categorical multifactorial experimental design with two factors (type of cement and cement content) was conducted to evaluate the interactions between the content and the type of cement on the S/S procedure. Finally, the most suitable type of 
cement was selected and subjected to a variance analysis in order to determine if changes in water content were statistically significant on the studied variable.

\section{Results and discussion}

\subsection{Characterization of the mixtures leachates}

In order to evaluate the chromium retention capacity of the mixtures, and therefore the effectiveness of the S/S treatment carried out, leaching tests were performed after 28 days of curing. Table 5 shows the mean values of the chromium content and toxicity of the obtained leachates (leaching tests were carried out in triplicate). The chromium content of the leachates is expressed as chromium concentration $(\mathrm{mg} / \mathrm{l})$ and as leached chromium $\left(\mathrm{mg} / \mathrm{kg}\right.$ mixture); the toxicity of the leachates is expressed as $\mathrm{EC}_{50}$ in $\%$ leachate dilution and in toxicity units (TU).

\section{Table 5}

Table 5 shows that the chromium concentration $(\mathrm{mg} / \mathrm{l})$ of the leachates obtained from the mixtures is, for all cases, lower than the chromium concentration in the leachate obtained from the original sludge (see Table 1), apparently showing that the S/S process is effective. The European regulations for the acceptance of wastes at landfills establish a leaching limit value for chromium of $0.1 \mathrm{mg} / \mathrm{l}$ for inert wastes, $2.5 \mathrm{mg} / \mathrm{l}$ for nonhazardous wastes, and $15 \mathrm{mg} / \mathrm{l}$ for hazardous wastes (European Commission, 2003b). According to this criteria, none of the mixtures could be disposed of at a non-hazardous waste landfill, despite having values close to $2.5 \mathrm{mg} / \mathrm{l}$. Additionally, the original sludge could not be disposed of at a hazardous waste landfill (see Table 1). However, these 
results are inconclusive because the aforementioned leaching limit values given by the European regulations correspond to leaching tests performed with distilled water (and with a solid/liquid ratio equal to $1 / 10$ ), whereas, in this work, leachates were obtained using acetic acid (and with a solid/liquid ratio equal to $1 / 20$ ).

The toxicity values of the leachates (Table 5) are all lower than the sludge leachates toxicity values (Table 1), showing an apparent effectiveness of the $\mathrm{S} / \mathrm{S}$ treatment. According to the Spanish regulations on the characterization of hazardous wastes (Seco et al., 2003; Spanish Government, 1989), a waste is ecotoxic if its acetic acid leachate shows an $\mathrm{EC}_{50}\left(15 \mathrm{~min}, 15^{\circ} \mathrm{C}\right)$ of greater than or equal to $333.3 \mathrm{TU}$. Table 5 shows that the mixtures leachates toxicity values are all lower than $333.3 \mathrm{TU}$; therefore, according to the Spanish regulations, the prepared mixtures are not ecotoxic and they could be catalogued as non-hazardous wastes. The sludge also shows a toxicity value lower than 333.3 TU (see Table 1); however, some authors (Seco et al., 2003) consider that the limit value established by the Spanish regulations is excessively tolerant, suggesting a limit value of $10 \mathrm{TU}$. The toxicity values of the mixtures leachates are much closer to $10 \mathrm{TU}$ than the sludge leachate toxicity value; however, only seven out of the total prepared mixtures show a value lower than 10 TU. Hence, despite the fact that contamination from tannery has been historically related to chromium releases (NietoCastillo et al., 2012), results show that the highest chromium concentrations of the mixtures leachates are not always associated with the highest toxicity values, consequently toxicity does not depend on the chromium concentration only. Some authors (Seco et al., 2003) also came to this conclusion working with different pollutants: the contaminating agent found in greater quantity is not always responsible 
for the waste toxicity. For instance, tannery sludge contains minor amounts of other heavy metals such as lead, nickel or zinc, which may also have significantly influence on the toxicity level.

The leached chromium from the mixtures expressed as $\mathrm{mg} \mathrm{Cr} / \mathrm{kg}$ mixture (Table 5) shows a clear decrease compared with the leached chromium from the sludge (see Table 1). In order to eliminate the dilution effect that might take place, Table 6 shows the leaching results as $\mathrm{mg} \mathrm{Cr} / \mathrm{kg}$ sludge and the percentage of chromium retention by the mixtures. Table 6 also shows the toxicity values of the leachates expressed as TU/ $/ \mathrm{kg}$ sludge/l); this parameter expresses the toxicity level given by the quantity of sludge present in the mass of mixture used to obtain one litre of leachate.

\section{Table 6}

The leached chromium from the mixtures expressed as $\mathrm{mg} \mathrm{Cr} / \mathrm{kg}$ sludge (Table 6) also shows a decrease compared with the leached chromium from the sludge (see Table 1). However, this decrease is lower than the one observed before in $\mathrm{mg} / \mathrm{kg}$ mixture and the difference is clearly due to the dilution effect. Moreover, chromium retention (Table 6) increases in the mixtures compared with the sludge (see Table 1); this increase is small due to the fact that chromium exhibits low mobility in tannery sludges (Chuan and Liu, 1996). The leachate toxicity expressed as $\mathrm{TU} /(\mathrm{kg}$ sludge/l) also decreases compared with the sludge. These results therefore, show the effectiveness of the S/S process. However, it should be noted again that the highest percentage of chromium retention is not always associated with the lowest toxicity values. 


\subsection{Effect of the relative amount of cement on the $S / S$ process}

The effect of relative amount of cement, type of cement and relative amount of water on the $\mathrm{S} / \mathrm{S}$ process were determined to find the minimum water and cement that provides the minimum toxicity to the mixture. Additionally, the amount of cement used should be optimized to reduce bulking which normally increase disposal costs.

The effect of the relative amount of cement on the S/S process was studied for cement M1 (CEM II/A-L 42.5 R) because it is the type of cement most commonly used in Spain to prepare concretes and mortars ordinary. Figure 1a shows the leached chromium as a function of the relative amount of cement M1. The values are expressed as $\mathrm{mg} \mathrm{Cr} / \mathrm{kg}$ mixture and, in order to eliminate the dilution effect, as $\mathrm{mg} \mathrm{Cr} / \mathrm{kg}$ sludge. The percentage of chromium retention is also plotted. According to the variance analysis, pvalue $(\mathrm{P})$ was lower than 0.05 , for all the analysed variables, indicating that the cement content significantly influences these variables.

\section{Figure 1}

The leached chromium calculated per mixture kilogram (Figure 1a) significantly diminishes $(\mathrm{P}<0.05)$ as the relative amount of cement in the mixtures increases. This fact could be due to the S/S process, or to a phenomenon of sludge replacement (the higher amount of cement in the mixtures, the lower amount of sludge), or a combination of both. If the observed decrease was only due to a dilution phenomenon, it would be expected that the leached chromium calculated per sludge kilogram would be constant, 
independent of the relative amount of cement used. Contrary, the leached chromium calculated per sludge kilogram (Figure 1a) significantly increases $(\mathrm{P}<0.05)$ with the relative amount of cement in the mixtures. This means that the effectiveness of the S/S process (referred to the chromium retention) decreases as the relative amount of cement increases. In fact, the percentage of chromium retention slightly decreases as the relative amount of cement increases (Figure 1a). This could be attributed to the chromium content of cement M1 (see Table 3); that is, as the relative amount of cement increases, more chromium (external to the sludge) is incorporated into the mixtures diminishing the effectiveness of the S/S process. The amount of water available for hydration may also affect the $\mathrm{S} / \mathrm{S}$ process.

The toxicity values do not exactly follow the same trend as the leached chromium. Figure $1 \mathrm{~b}$ shows the toxicity values of the leachates as $\mathrm{EC}_{50}$ in toxicity units (TU). In general, toxicity seems to diminish as the relative amount of cement increases, indicating that toxicity could be related directly with the chromium concentration in the leachate. However, there is an exception. The mixture with $30 \%$ cement presents the minimum value of toxicity. Therefore, toxicity does not only depend on the chromium concentration in the leachate. On the other hand, in order to eliminate the dilution effect that take place, toxicity has also been calculated per sludge kilogram per litre of leachate $(\mathrm{TU} /(\mathrm{kg}$ of sludge/l)) and Figurelb also shows these results. The new toxicity values increase as the relative amount of cement increases; then, diminish, showing a minimum for the same mixture with $30 \%$ cement. Finally, there is an increase again as the relative amount of cement increases. This increase in toxicity level could be 
attributed to an excess of cement M1, which could provide some toxicity to the mixtures (Table 3).

In summary, the lowest leached chromium calculated per mixture kilogram corresponds to the highest relative amount of cement. However, the highest chromium retention (\%) corresponds to the lowest relative amount of cement. The mixture with $30 \%$ cement had the lowest toxicity. Additionally, low toxicity values were obtained for 40 and $50 \%$ cement contents, compared to the rest of mixtures (Figure 1b).

The volume increase that takes place after preparing the mixtures is another point to take into account. Density of the mixtures was experimentally determined and volume increase was calculated. Figure 2 shows the effect of the relative amount of cement on the volume increase. As it was expected, the minimum volume increase corresponds to the mixture with the lowest amount of cement. The volume increase increases as more sludge is substituted by cement. However, below the $30 \%$ of cement, the enhancement of the volume increase is less steep, whereas above the $30 \%$ of cement, volume increase is sharper.

\section{Figure 2}

\subsection{Effect of the type of cement on the $S / S$ process}

Additives (such as pozzolans and fly ashes) were used to initiate, catalyze or, in general, to improve the characteristics of agglutinating agents and the agglutinating reactions between reagents and wastes. In order to study the effect of the type of cement on the 
S/S process, two commercial Portland cements M2 and M3 were used. A multifactorial experimental design with two factors: type of cement (cement M1: CEM II/A-L 42.5 R, cement M2: CEM II/B-M (V-LL) $32.5 \mathrm{~N}$ and cement M3: CEM II/B-P $32.5 \mathrm{~N}$ ) and cement content was used. Figure 3 shows the interactions plots for the three analysed cements and for the different cement contents. For all the response variables (leached chromium, toxicity and volume increase), the p-value of the interaction corresponding to both type and content of cement is lower than 0.05 . Therefore, the influence of the cement content on the studied variables depends on the type of cement.

\section{Figure 3}

Figure 3a shows the leached chromium (expressed as $\mathrm{mg} \mathrm{Cr} / \mathrm{kg}$ mixture and as $\mathrm{mg}$ $\mathrm{Cr} / \mathrm{kg}$ sludge) and the percentage of chromium retention as a function of the relative amount of cement for cements M1, M2 and M3. For the three cements, the leached chromium calculated per mixture kilogram reduces (except for cement M2 with $50 \%$ cement), whereas the leached chromium calculated per sludge kilogram increases as the relative amount of cement increases. Therefore, for all analysed cements, the effectiveness of the S/S process (referred to the chromium retention) decreases as the relative amount of cement increases. In fact, the percentage of chromium retention slightly decreases as the relative amount of cement increases (Figure 3a). As it has been suggested before, this fact could be attributed to the additional chromium provided by the cements (see Table 3). On the other hand, the leached chromium values are very similar for the three analysed cements, although they seem slightly lower for the cement M2, except for the mixture with $50 \%$ cement. 
Figure $3 b$ shows toxicity values of the leachates $\left(\mathrm{EC}_{50}\right)$ as a function of the relative amount of cement for cements M1, M2 and M3. For all analysed cements, and independent of the units used (TU or TU/(kg of sludge/l)), toxicity presents a minimum value. This value is very similar for the three cements, but depends on the relative amount of cement used. Generally, different amounts of clinker in each cement might have had a greater influence on the overall results (Table 2). For cement M1, the mixture with $30 \%$ cement contains a $25.2 \%(30 \times 0.84)$ of relative amount of clinker in the solid components; and for cements M2 and M3, the mixtures with $40 \%$ cement contain a $27.6 \%(40 \times 0.69)$ and $27.2 \%(40 \times 0.68)$ of relative amount of clinker in the solid components respectively. Therefore, the same percentage of clinker is needed to achieve the same minimum toxicity value in the resulting mixtures, independent of the type of cement used. That is, clinker seems to be the material responsible for the effectiveness of the S/S process, and additives such as pozzolans or fly ashes have insignificant influence. The increase in toxicity level could be attributed to excess cement, which could provide some toxicity to the mixtures as has been aforementioned.

On the other hand, Figure 2 shows the effect of the relative amount of cement on the volume increase for cements M1, M2 and M3. As it was expected, for the three cements, the volume increase is greater as more sludge is replaced by cement. However, values are very similar for cements M2 and M3, but greater than for cement M1.

Cements M2 and M3 are cheaper than cement M1, but greater amounts are needed to achieve the same minimum toxicity value in the resulting mixtures. According to the 
manufacturer's prices, the price of cement M1 is approximately 85 euros/ton without taking into account the costs of transport and distribution, whereas cements M2 or M3 are 10 euros cheaper. Therefore, for treating 1 ton of tannery sludge according to the mixture M1-40-30, 428.6 kg of cement M1 are needed, which costs 36.4 euros, whereas for treating 1 ton of tannery sludge according to the mixtures M2-40-40 or M3-40-40, $666.7 \mathrm{~kg}$ of cement M2 or M3 are needed, which costs 50 euros. Moreover, the volume increase is greater for cements M2 and M3, increasing the disposal cost of the resulting mixtures in a landfill. Therefore, cement M1 seems to be more appropriate from an economic point of view.

\subsection{Effect of the relative amount of water on the $S / S$ process}

The results obtained showed that cements M2 and M3 do not improve results more than those obtained with cement M1. However, it is technically important to determine the effect of the relative amount of water on the S/S process especially for cement M1.

Cement M1 data (which showed the best results) were subjected to variance analysis (ANOVA), using the least significant difference (LSD) test with a 95\% confidence interval. ANOVA analysis was used in order to determine if variations on water content significantly influence the S/S process. Since the p-values obtained were lower than 0.05 , for all the studied variables, the water content has a significant effect on the $\mathrm{S} / \mathrm{S}$ process.

\section{Figure 4}


Figure 4a shows the leached chromium and the percentage of chromium retention as a function of the relative amount of water. The leached chromium calculated per mixture kilogram slightly decreases as the relative amount of water increases; however, the leached chromium calculated per sludge kilogram increases as the relative amount of water increases. Thus, the effectiveness of the $\mathrm{S} / \mathrm{S}$ process decreases as the relative amount of water increases. In fact, the percentage of chromium retention slightly decreases as the relative amount of water increases (Figure 4a). This could be attributed to the density of the resulting mixtures, which slightly decreases as the relative amount of water increases $\left(1,41,1,36\right.$ and $1,29 \mathrm{~g} / \mathrm{cm}^{3}$, for 30,40 and $50 \%$ of relative amount of water, respectively), probably due to an increase in the porosity, which may increase chromium leaching capacity.

Figure $4 \mathrm{~b}$ shows toxicity values of the leachates $\left(\mathrm{EC}_{50}\right)$ as a function of the relative amount of water. Independent of the units used (TU or TU/(kg of sludge/l)), toxicity presents a maximum value for the mixture with $40 \%$ relative amount of water, showing again that toxicity does not depends on the chromium concentration in the leachate only. As has been aforementioned, the other heavy metals contained in tannery sludge may also influence the toxicity level.

On the other hand, Figure 5 shows the effect of the relative amount of water on the volume. The minimum volume increase corresponds to the mixture with the lowest amount of water. The volume increase is significantly greater $(\mathrm{P}<0.05)$ as more cement plus sludge are substituted by water. However, the difference between $30 \%$ and $40 \%$ of 
water is less steep, while the difference between $40 \%$ and $50 \%$ of water is much sharper.

\section{Figure 5}

In summary, the lowest leached chromium calculated per mixture kilogram corresponds to the highest relative amount of water. However, the best chromium retention corresponds to the lowest relative amount of water (30\%). On the other hand, toxicity and volume increase were lower in the mixture with $30 \%$ water.

\section{Conclusions}

A S/S process using cement was applied to tannery sludge in order to find a safer way of landfilling this waste to reduce its hazardous intrinsic characteristics. The effectiveness of the process was analysed in terms of leachate toxicity and percentage chromium retention. The following conclusions may be made:

1. The S/S process with cement is effective and does not cause a dilution of the sludge only.

2. Toxicity of the mixtures does not only depend on the chromium concentration in the leachate, but also other heavy metals such as lead, nickel or zinc, which are present in minor amounts in tannery sludge.

3. Statistical analysis reveals that all the studied parameters (cement content, type of cement and water content) significantly influence the effectiveness of the S/S process. 
4. The effectiveness of the $\mathrm{S} / \mathrm{S}$ process (referred to the chromium retention) slightly decreases as the relative amount of cement increases. This could be attributed to additional chromium provided by cement.

5. The effectiveness of the $\mathrm{S} / \mathrm{S}$ process (referred to the chromium retention) slightly decreases as the relative amount of water increases. This could be attributed to an increase in the porosity of the resulting mixtures.

6. Toxicity values for the mixture with $30 \%$ cement without additions of fly ashes or pozzolans, and for the mixtures with $40 \%$ cement with additions of fly ashes or pozzolans show minimum levels. However, the increase in toxicity level from this toxicity increases as the amount of cement increases. This could be attributed to excess cement.

7. Clinker seems to be the material responsible for the effectiveness of the S/S process whereas additives such as pozzolans or fly ashes do not improve it.

8. The volume increase of the mixtures decreases as less sludge is replaced by cement and as the relative amount of water decreases. Moreover, the values are lower for the cement without additions of fly ashes or pozzolans.

9. Cement without additions of fly ashes or pozzolans seems to be more appropriate in spite of being more expensive, since a lower amount of cement is needed to achieve the same minimum toxicity value in the resulting mixtures. Additionally, the volume increase in the mixtures is lower, reducing the disposal cost to a landfill. 


\section{Acknowledgements}

The authors wish to express their gratitude to the tannery facility INCUSA, S.A., to the cement facility CEMEX ESPAÑA, S.A. and to Carles Martínez for his translation assistance.

\section{References}

Alunno-Rossetti V., Di-Palma L., Medici F., 2002. Assessment of the leaching of metallic elements in the technology of solidification in aqueous solution, Waste Manage. 22, 605-610.

Aydin A.A., Aydin A., 2014. Development of an immobilization process for heavy metal containing Galvanic solid wastes by use of sodium silicate and sodium tetraborate, J. Hazard. Mater. 270, 35-44.

Basegio T., Beck Leão A.P., Bernardes A.M., Bergmann C.P., 2009. Vitrification: An alternative to minimize environmental impact caused by leather industry wastes, J. Hazard. Mater. 165, 604-611.

Bundesrat, 1990. Zweite allgemeine Verwaltungsvorschrift zum Abfallgesetz (TAAbfall), GMDI 170, Germany.

Cassano A., Drioli E., Molinari R., Bertolutti C., 1996. Quality improvement of recycled chromium in the tanning operation by membrane processes, Desalination 108, 193-203.

Chuan M.C., Liu J.C., 1996. Release behavior of chromium from tannery sludge, Water Res. 30, 932-938.

Conner J.R., 1990. Chemical fixation and solidification of hazardous wastes, Van Nostrand Reinhold, New York. 
EN 14346, 2006. Characterization of waste - calculation of dry matter by determination of dry residue or water content.

Erdem M., Özverdi A., 2008. Leaching behavior of chromium in chrome shaving generated in tanning process and its stabilization, J. Hazard. Mater. 156, 51-55.

European Commission, 2003a. Reference Document on Best Available Techniques for the Tanning of Hides and Skins. IPTS, Seville. URL http://www.eippcb.jrc.es (Accessed 17-05-2012).

European Commission, 2003b. Council Decision 2003/33/EC which establishes criteria and procedures for the acceptance of waste at landfills. Official Journal of the European Communities L 11, 27-49.

European Commission, 2000. Commission Decision 2000/532/EC which establishes the European Waste List. Official Journal of the European Communities L 226, 3-24.

Houshyar Z., Khoshfetrat A.B., Fatehifar E., 2012. Influence of ozonization process on characteristics of pre-alkalized tannery effluents, Chem. Eng. J. 191, 59-65.

Kiliç E., Puig R., Baquero G., Font J., Çolak S., Gürler D., 2011. Environmental optimization of chromium recovery from tannery sludge using a life cycle assessment approach, J. Hazard. Mater. 192, 393-401.

Kogbara R.B., Al-Tabbaa A., Yi Y., Stegemann J.A., 2013. Cement-fly ash stabilisation/solidification of contaminated soil: Performance properties and initiation of operating envelopes, Appl. Geochem. 33, 64-75.

Krishnamoorthy G., Sadulla S., Sehgal P.K., Mandal A.B., 2012. Green chemistry approaches to leather tanning process for making chrome-free leather by unnatural amino acids, J. Hazard. Mater. 215-216, 173-182. 
Li X., He C., Bai Y., Ma B., Wang G., Tan H., 2014. Stabilization/solidification on chromium (III) wastes by C3A and C3Ahydrated matrix, J. Hazard. Mater. 268, 61-67. Nashy E.S.H.A., Al-Ashkar E., Moez A.A., 2012. Optical and spectroscopic studies on tannery wastes as a possible source of organic semiconductors, Spectrochim. Acta A. $86,33-38$.

Navarro-Blasco I., Duran A., Sirera R., Fernandez J.M., Alvarez J.I., 2013. Solidification/stabilization of toxic metals in calcium aluminate cement matrices, J. Hazard. Mater. 260, 89-103.

Nieto-Castillo A.,. García-Delgado R.A, Cala-Rivero V., 2012. Electrokinetic of solids contaminated by tannery waste, Electrochim. Acta 86, 110-114.

Ogunbileje J.O., Sadagoparamanujam V.M., Anetor J.I., Farombi E.O., Akinosun O.M., Okorodudu A.O., 2013. Lead, mercury, cadmium, chromium, nickel, copper, zinc, calcium, iron, manganese and chromium (VI) levels in Nigeria and United States of America cement dust, Chemosphere 90, 2743-2749.

Peysson S., Péra J., Chabannet M., 2005. Immobilization of heavy metals by calcium sulfoaluminate cement, Cement Concrete Res. 35, 2261-2270.

Piccin J.S., Gomes C.S., Feris L.A., Gutterres M., 2012. Kinetics and isotherms of leather dye adsorption by tannery solid waste, Chem. Eng. J. 183, 30-38.

Rodríguez J.J., Irabien A., 1999. Los residuos peligrosos. Caracterización, tratamiento y gestión (Hazardous wastes. Characterization, treatment and management), Síntesis, Madrid.

Seco J.I., Fernández-Pereira C., Vale J., 2003. A study of the leachate toxicity of metalcontaining solid wastes using Daphnia magna, Ecotox. Environ. Safe. 56, 339-350. 
Shakir L., Ejaz S., Ashraf M., Qureshi N.A., Anjum A.A., Iltaj I., Javeed A., 2012. Ecotoxicological risks associated with tannery effluent wastewater, Environ. Toxicol. Phar. 34, 180-191.

Silva M.A.R., Mater L., Souza-Sierra M.M., Correa A.X.R., Sperb R., Radetski C.M., 2007. Small hazardous waste generators in developing countries: use of stabilization/solidification process as an economic tool for metal wastewater treatment and appropriate sludge disposal, J. Hazard. Mater. 147, 986-990.

Spanish Government, 2002. Spanish Royal Decree 1481/2001 which establishes regulations on disposing of wastes in a landfill. Boletín Oficial del Estado (Official State Gazette) 25, 3507-3521.

Spanish Government, 1989. Spanish Order of October 13th 1989 which establishes the methods of characterization of hazardous wastes. Boletín Oficial del Estado (Official State Gazette) 270, 35216-35222.

Sundarapandiyan S., Brutto P.E., Siddhartha G., Ramesh R., Ramanaiah B., Saravanan P., Mandal A.B., 2011. Enhancement of chromium uptake in tanning using oxazolidine, J. Hazard. Mater. 190, 802-809.

Swarnalatha S., Srinivasulu T., Srimurali M., Sekaran G., 2008. Safe disposal of toxic chrome buffing dust generated from leather industries, J. Hazard. Mater. 150, 290-299. Torras J., Buj I., Rovira M., de Pablo J., 2012. Chromium recovery from exhausted baths generated in plating processes and its reuse in the tanning industry, J. Hazard. Mater. 209-210, 343-347.

Ucaroglu S., Talinli I., 2012. Recovery and safer disposal of phosphate coating sludge by solidification/stabilization, J. Environ. Manage. 105, 131-137. 
US Environmental Protection Agency, 1998. Identification and Listing of Hazardous Waste, Title 40 Code Federal Regulations (CFR). Part 261, App VIII (Chapter 1), US Environmental Protection Agency, Washington D.C.

Viñals J., Balart M.J., Roca A., 2002. Inertization of pyrite cinders and co-inertization with electric arc furnace flue dusts by pyroconsolidation at solid state, Waste Manage. $22,773-782$.

Yoon I.H., Moon D.H., Kim K.W., Lee K.Y., Lee J.H., Kim M.G., 2010. Mechanism for the stabilization/solidification of arsenic-contaminated soils with Portland cement and cement kiln dust, J. Environ. Manage. 91, 2322-2328. 


\section{Figure captions}

Figure 1. Effect of the relative amount of cement (CEM II/A-L 42.5 R) on the S/S process.

Figure 2. Effect of the relative amount of cement and the type of cement on the volume increase. Cement M1: CEM II/A-L 42.5 R; cement M2: CEM II/B-M (V-LL) 32.5 N; and cement M3: CEM II/B-P 32.5 N.

Figure 3. Effect of the type of cement on the S/S process. Cement M1: CEM II/A-L 42.5 R; cement M2: CEM II/B-M (V-LL) 32.5 N; and cement M3: CEM II/B-P 32.5 N.

Figure 4. Effect of the relative amount of water on the S/S process with CEM II/A-L $42.5 \mathrm{R}$.

Figure 5. Effect of the relative amount of water on the volume increase (cement CEM II/A-L 42.5 R).

\section{Table legends}

Table 1. Tannery sludge characterization.

Table 2. Cements average composition (wt.\%) supplied by the manufacturer.

Table 3. Cements characterization.

Table 4. Experimental tests carried out.

Table 5. Chromium content and leachate toxicity of the mixtures after 28 days of curing.

Table 6. Effectiveness of the S/S process. 
a) Leaching

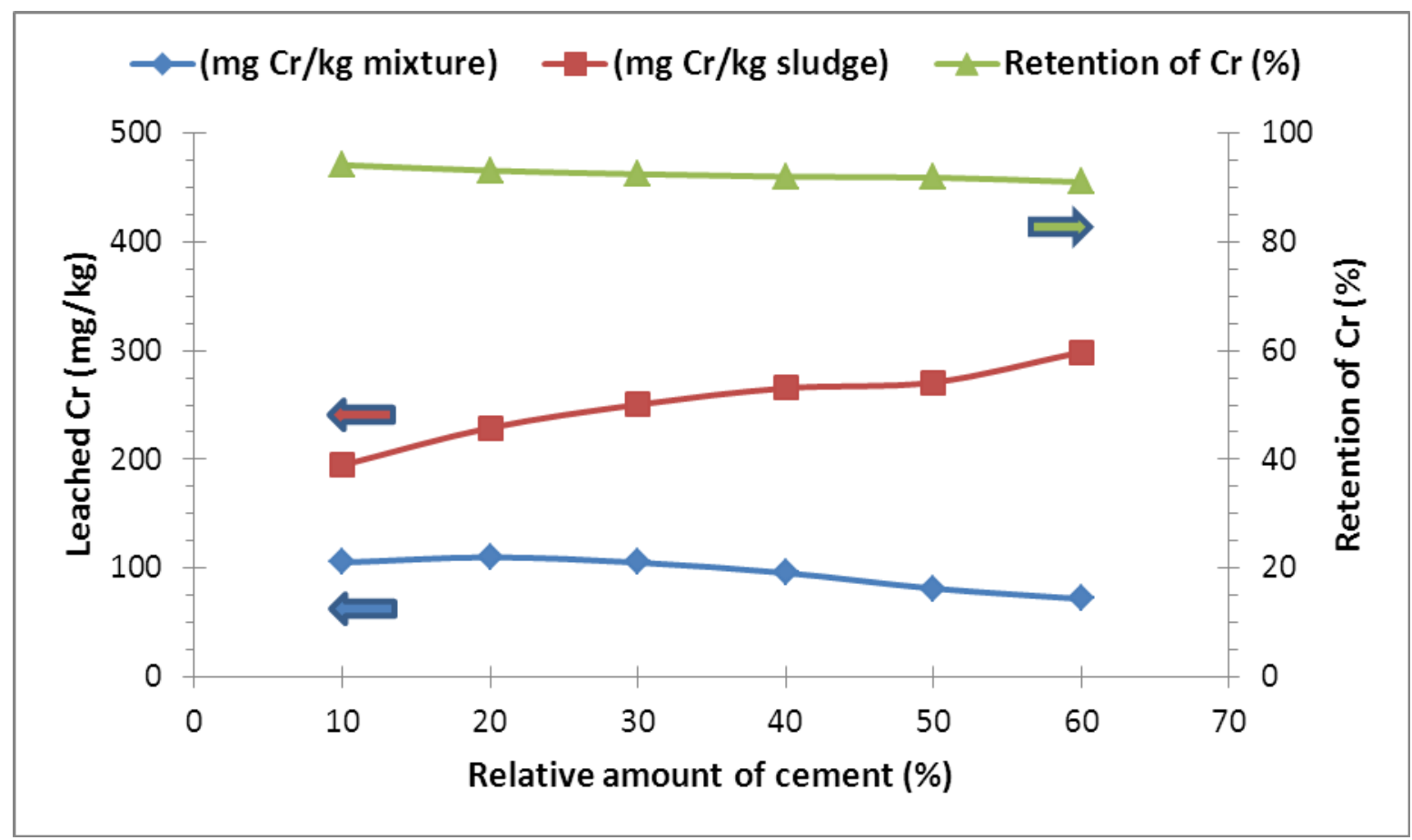

\section{b) Toxicity}

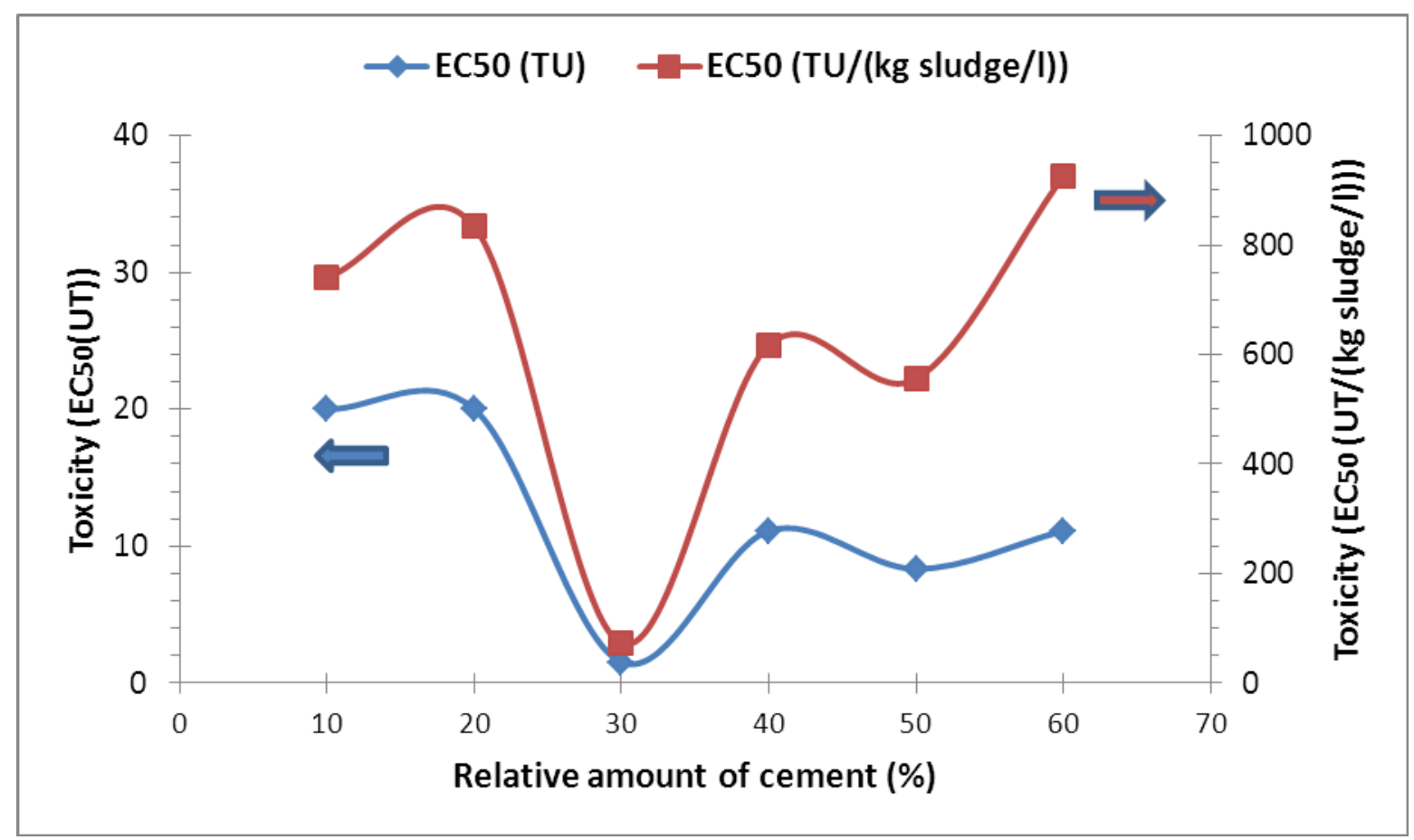




\section{Figure 2}

Click here to download Figure: Figure2.pdf

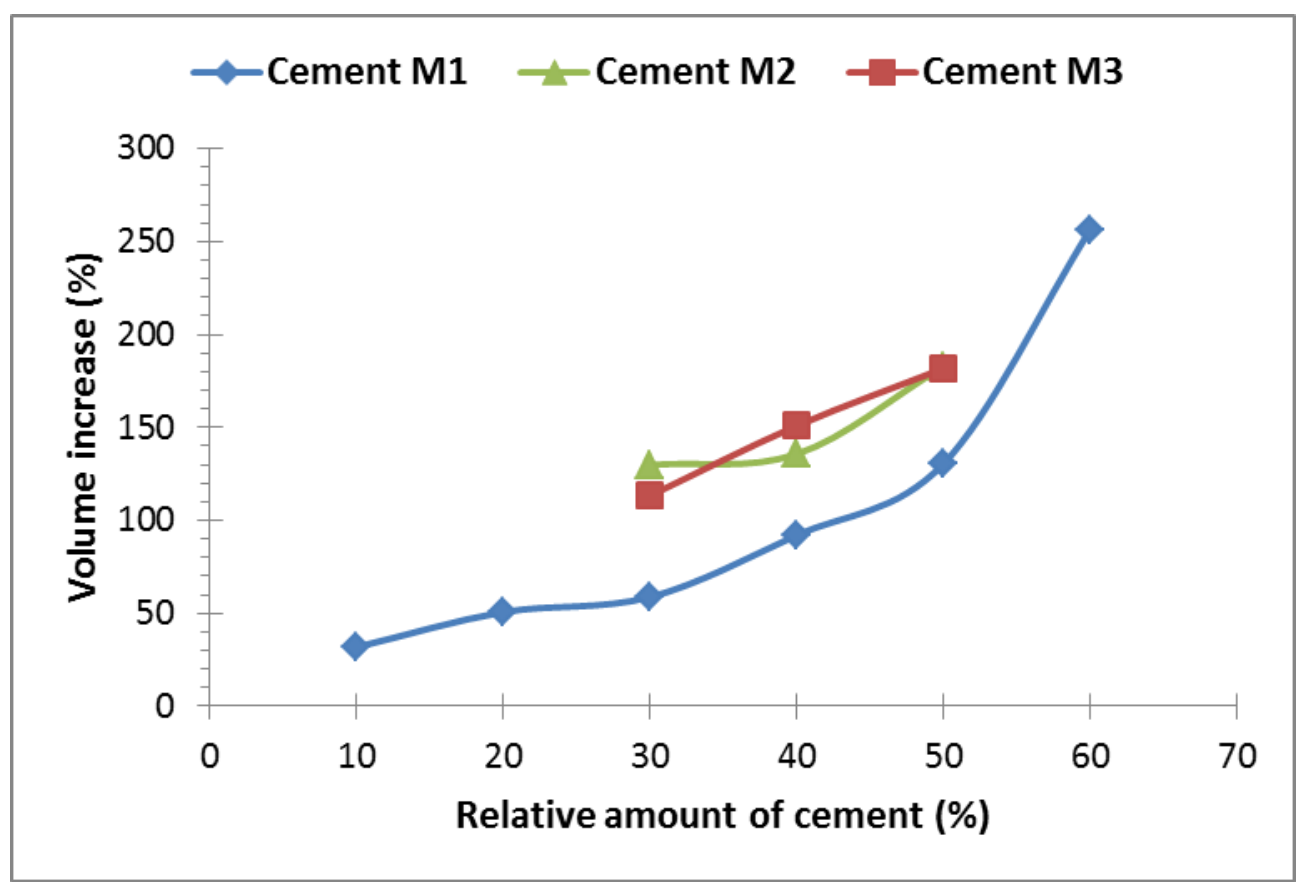




\section{a) Leaching}

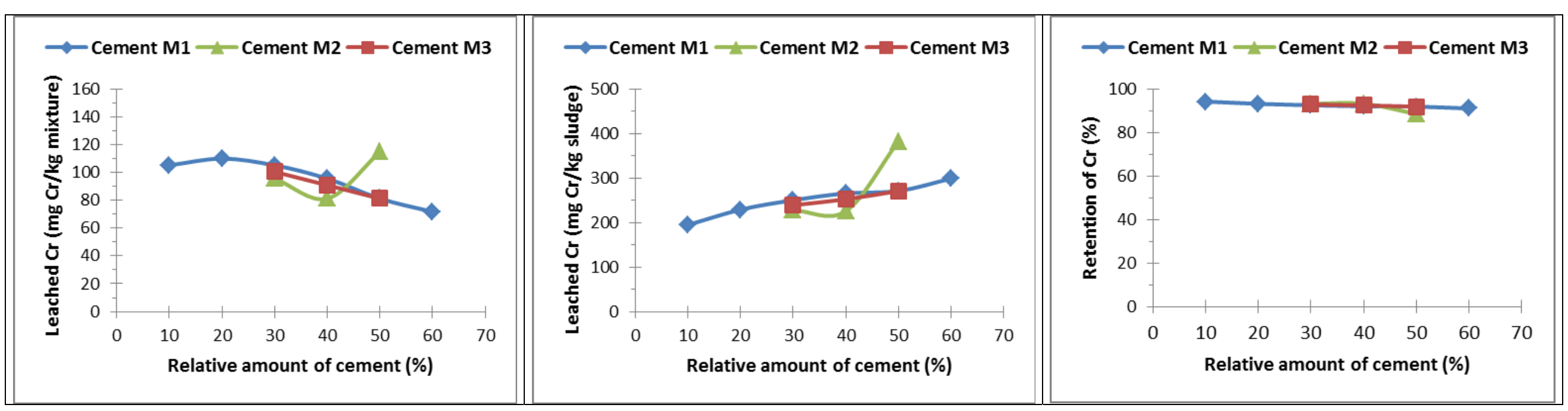

\section{b) Toxicity}

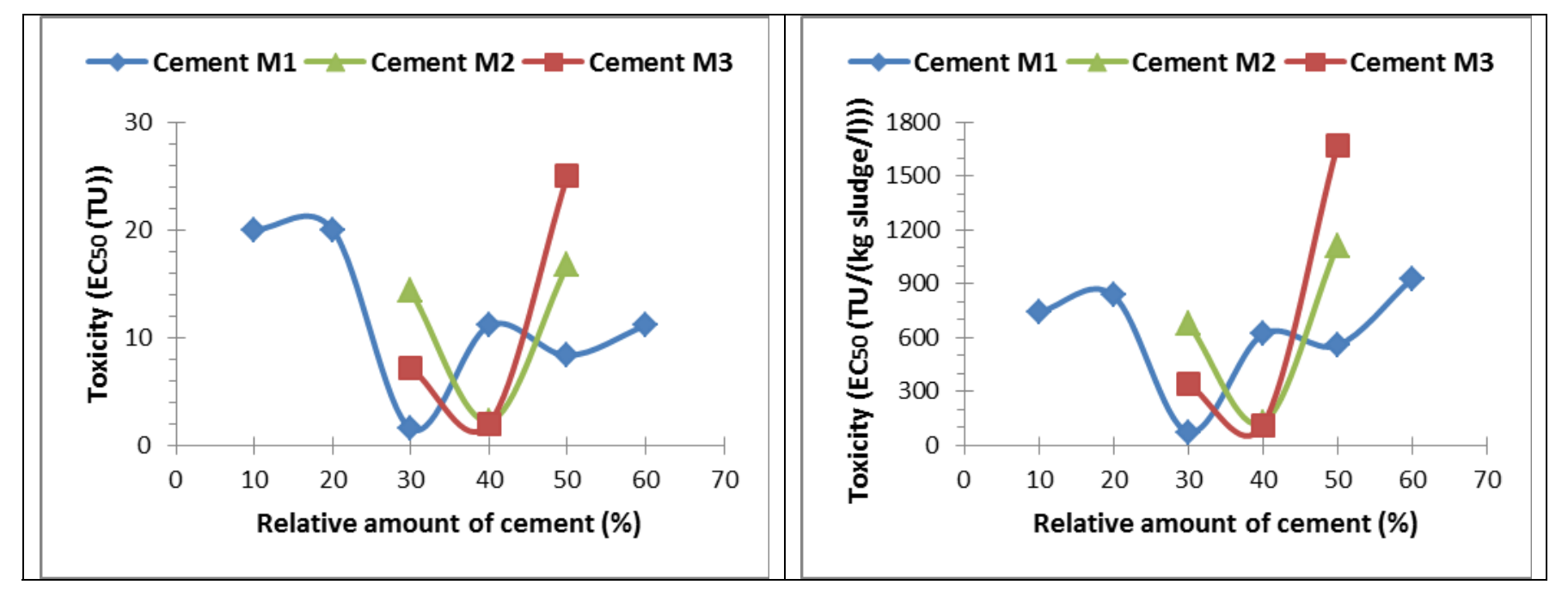


a) Leaching

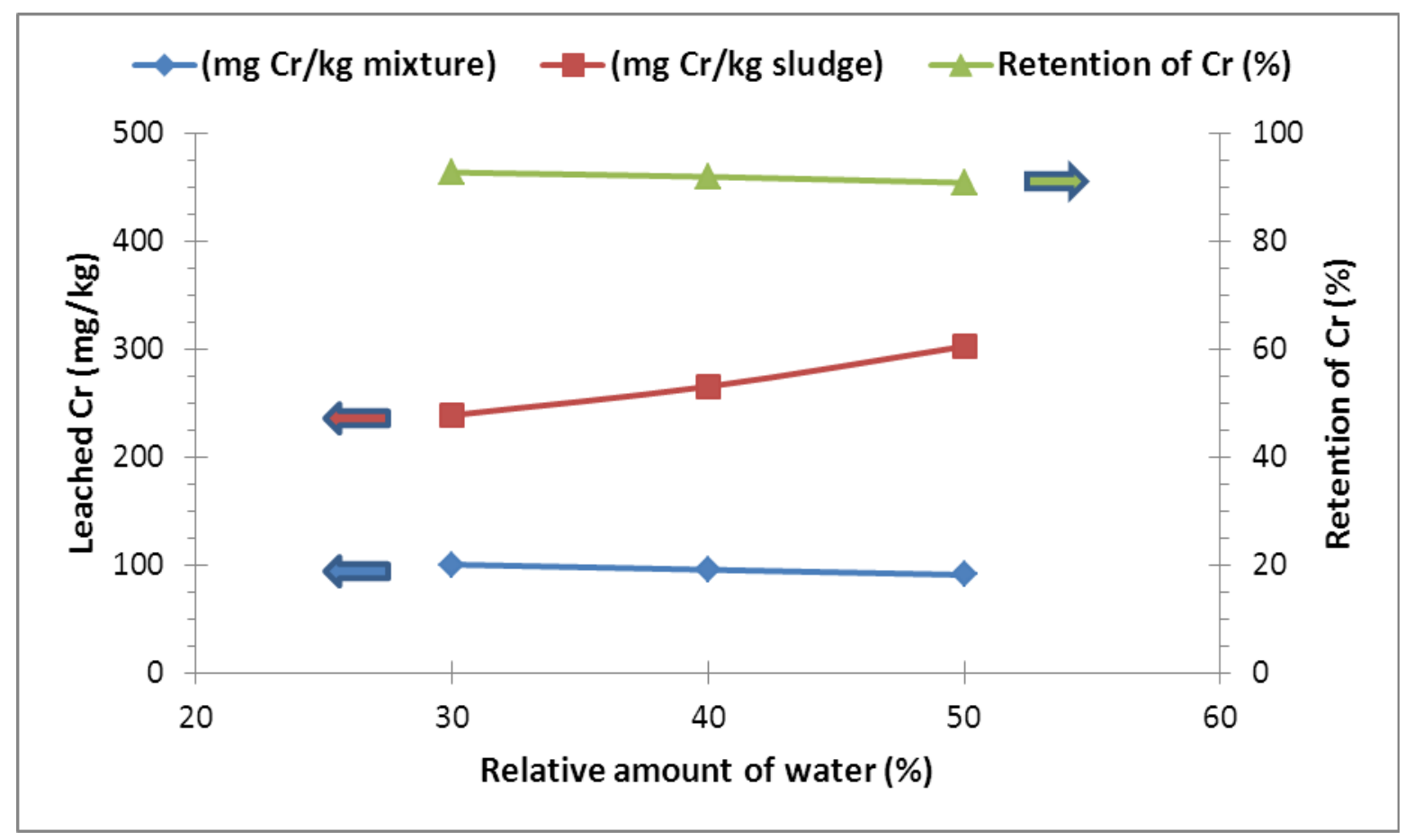

\section{b) Toxicity}

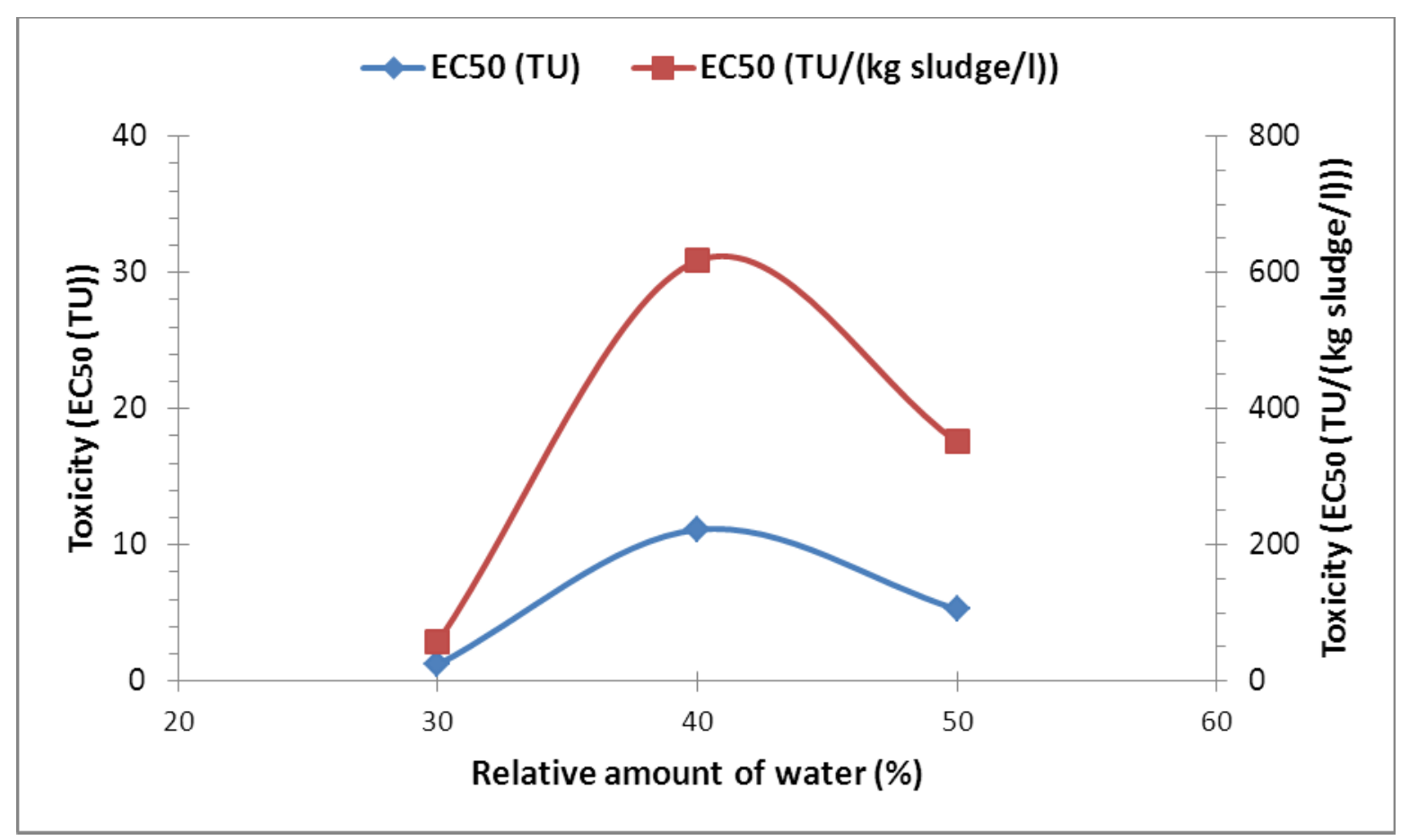


Figure 5

Click here to download Figure: Figure5.pdf

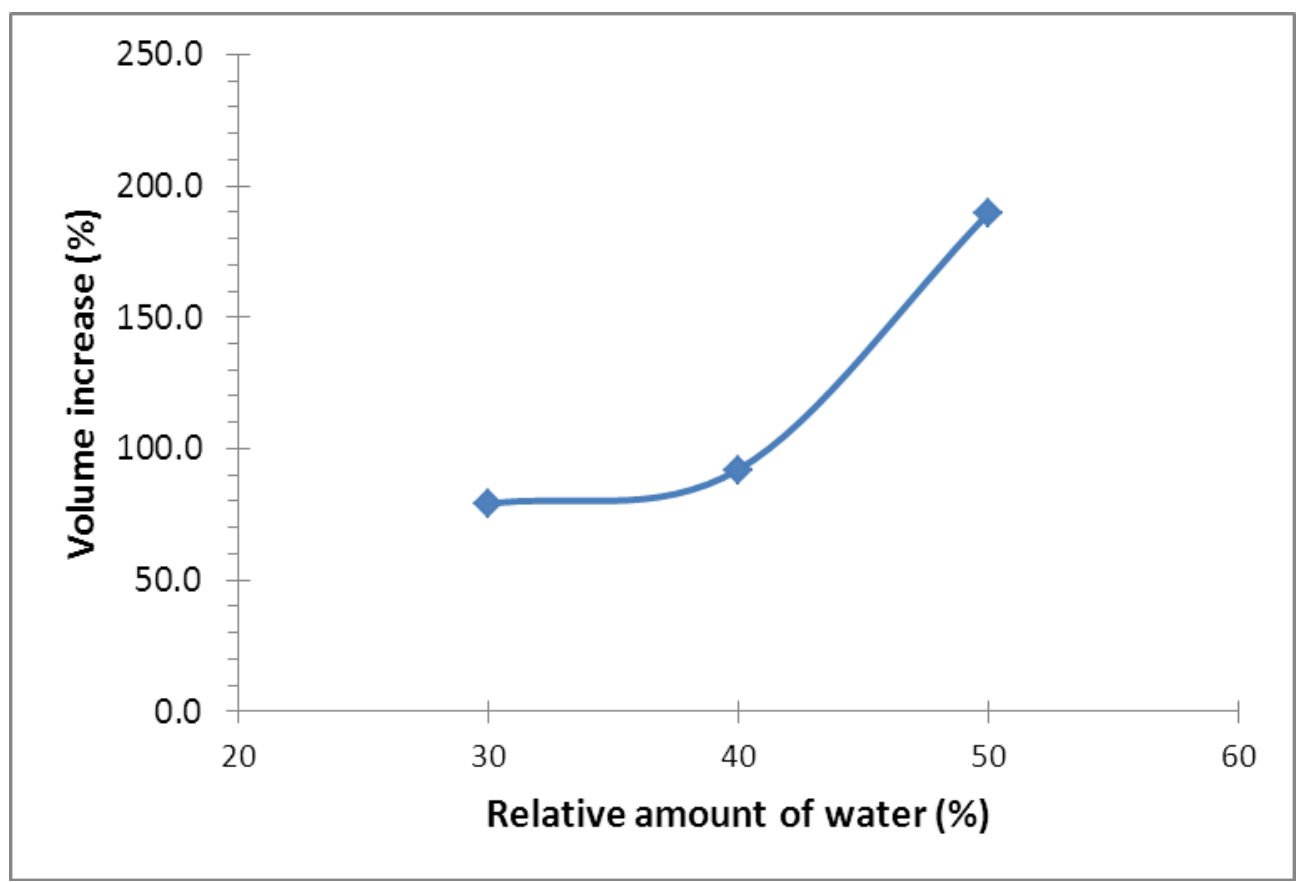




\section{Table 1}

Tannery sludge characterization.

\begin{tabular}{lc}
\multicolumn{1}{c}{ Parameter } & Value \\
\hline Moisture (wt.\%) & $58 \pm 4$ \\
Density (kg/l) & $1.05 \pm 0.09$ \\
{$[\mathrm{Cr}](\mathrm{mg} / \mathrm{kg}$ dry matter $)$} & $7903 \pm 58$ \\
Leachate characteristics: & \\
{$[\mathrm{Cr}](\mathrm{mg} / \mathrm{l})$} & 385 \\
Leached Cr $(\mathrm{mg} / \mathrm{kg}$ sludge $)$ & 88.4 \\
Retention of Cr $(\%)$ & $0.8 \pm 0.1$ \\
Leachate toxicity $\left(\mathrm{EC}_{50}(\%\right.$ leachate dilution $\left.)\right)$ & 125 \\
Leachate toxicity $\left(\mathrm{EC}_{50}(\mathrm{TU})\right)$ & 2501 \\
\hline Leachate toxicity $\left(\mathrm{EC}_{50}(\mathrm{TU} /(\mathrm{kg}\right.$ sludge/l $\left.))\right)$ &
\end{tabular}




\begin{tabular}{|c|c|c|c|c|c|}
\hline $\begin{array}{l}\text { Binders based on } \\
\text { Portland cement }\end{array}$ & Clinker & $\begin{array}{l}\text { Pozzolan } \\
\text { additives }\end{array}$ & Fly ash & Limestone & $\begin{array}{l}\text { Additional } \\
\text { components }\end{array}$ \\
\hline Cement M1: CEM II/A-L 42.5 R & 84 & - & - & 12 & 2 \\
\hline Cement M2: CEM II/B-M (V-LL) $32.5 \mathrm{~N}$ & 69 & - & 11 & 15 & 5 \\
\hline Cement M3: CEM II/B-P $32.5 \mathrm{~N}$ & 68 & 27 & - & - & 5 \\
\hline
\end{tabular}


Click here to download Table: Table3.doc

\section{Table 3}

Cements characterization

\begin{tabular}{lrrr}
\hline \multicolumn{1}{c}{ Parameter } & Cement M1 & Cement M2 & Cement M3 \\
\hline [Cr] (mg/kg dry matter) & $358 \pm 13$ & $393 \pm 5$ & $449 \pm 14$ \\
Leachate characteristics: & & & \\
{$[\mathrm{Cr}](\mathrm{mg} / \mathrm{l})$} & $1.11 \pm 0.08$ & $0.86 \pm 0.09$ & $2.56 \pm 0.21$ \\
Leached Cr (mg/kg cement) & 22.20 & 17.28 & 51.21 \\
Retention of Cr (\%) & 93.8 & 95.6 & 88.6 \\
Leachate toxicity $\left(\mathrm{EC}_{50}(\%\right.$ leachate dilution) $)$ & $0.6 \pm 0.0$ & $1.7 \pm 0.1$ & $0.8 \pm 0.1$ \\
Leachate toxicity $\left(\mathrm{EC}_{50}(\mathrm{TU})\right)$ & 167 & 59 & 125 \\
Leachate toxicity $\left(\mathrm{EC}_{50}(\mathrm{TU} /(\mathrm{kg}\right.$ cement/l) $))$ & 3333 & 1177 & 2500 \\
\hline
\end{tabular}


Table 4

Experimental tests carried out

\begin{tabular}{|c|c|c|c|c|}
\hline \multirow[b]{2}{*}{ Cement } & \multirow[b]{2}{*}{ Mixture } & \multirow{2}{*}{$\begin{array}{c}\text { Water } \\
\text { added } \\
(w t . \%)\end{array}$} & \multicolumn{2}{|c|}{ Solid (Bal.) } \\
\hline & & & $\begin{array}{c}\text { Cement } \\
\text { (wt.\%) }\end{array}$ & $\begin{array}{l}\text { Sludge } \\
\text { (wt.\%) }\end{array}$ \\
\hline \multirow{8}{*}{$\begin{array}{l}\text { CEM II/A-L 42.5 R } \\
\text { (cement M1) }\end{array}$} & M1-30-40 & 30 & 40 & 60 \\
\hline & M1-40-10 & \multirow{6}{*}{40} & 10 & 90 \\
\hline & M1-40-20 & & 20 & 80 \\
\hline & M1-40-30 & & 30 & 70 \\
\hline & M1-40-40 & & 40 & 60 \\
\hline & M1-40-50 & & 50 & 50 \\
\hline & M1-40-60 & & 60 & 40 \\
\hline & M1-50-40 & 50 & 40 & 60 \\
\hline \multirow{3}{*}{$\begin{array}{l}\text { CEM II/B-M (V-LL) } 32.5 \mathrm{~N} \\
\text { (cement M2) }\end{array}$} & M2-40-30 & \multirow{3}{*}{40} & 30 & 70 \\
\hline & M2-40-40 & & 40 & 60 \\
\hline & M2-40-50 & & 50 & 50 \\
\hline \multirow{3}{*}{$\begin{array}{l}\text { CEM II/B-P } 32.5 \mathrm{~N} \\
\text { (cement M3) }\end{array}$} & M3-40-30 & \multirow{3}{*}{40} & 30 & 70 \\
\hline & M3-40-40 & & 40 & 60 \\
\hline & M3-40-50 & & 50 & 50 \\
\hline
\end{tabular}


Table 5

Chromium content and leachate toxicity of the mixtures after 28 days of curing.

\begin{tabular}{|c|c|c|c|c|}
\hline \multirow{2}{*}{ Mixture } & \multicolumn{2}{|c|}{ Leachate chromium content } & \multicolumn{2}{|c|}{ Leachate toxicity } \\
\hline & $\begin{array}{c}{[\mathrm{Cr}]} \\
(\mathrm{mg} / \mathrm{l})\end{array}$ & $\begin{array}{c}\text { Leached Cr } \\
\text { (mg/kg mixture) }\end{array}$ & $\begin{array}{c}\mathrm{EC}_{50} \\
(\%)\end{array}$ & $\begin{array}{l}\mathbf{E C}_{50} \\
(\mathrm{TU})\end{array}$ \\
\hline M1-30-40 & $5.0 \pm 0.3$ & 100.4 & 83 & $1.2 \pm 0.1$ \\
\hline M1-40-10 & $5.3 \pm 0.4$ & 105.1 & 5 & $20.0 \pm 1.8$ \\
\hline M1-40-20 & $5.5 \pm 0.4$ & 109.9 & 5 & $20.0 \pm 1.7$ \\
\hline M1-40-30 & $5.3 \pm 0.4$ & 105.1 & 66 & $1.5 \pm 0.2$ \\
\hline M1-40-40 & $4.8 \pm 0.3$ & 95.6 & 9 & $11.1 \pm 0.7$ \\
\hline M1-40-50 & $4.1 \pm 0.2$ & 81.2 & 12 & $8.3 \pm 0.7$ \\
\hline M1-40-60 & $3.6 \pm 0.2$ & 71.7 & 9 & $11.1 \pm 0.6$ \\
\hline M1-50-40 & $4.5 \pm 0.3$ & 90.8 & 19 & $5.3 \pm 0.2$ \\
\hline M2-40-30 & $4.8 \pm 0.5$ & 95.6 & 7 & $14.3 \pm 0.8$ \\
\hline M2-40-40 & $4.1 \pm 0.3$ & 81.2 & 45 & $2.2 \pm 0.1$ \\
\hline M2-40-50 & $5.7 \pm 0.5$ & 114.7 & 6 & $16.7 \pm 1.5$ \\
\hline M3-40-30 & $5.0 \pm 0.1$ & 100.4 & 14 & $7.1 \pm 0.5$ \\
\hline M3-40-40 & $4.5 \pm 0.3$ & 90.8 & 50 & $2.0 \pm 0.1$ \\
\hline M3-40-50 & $4.1 \pm 0.3$ & 81.2 & 4 & $25.0 \pm 1.9$ \\
\hline
\end{tabular}


Table 6

Effectiveness of the solidification/stabilization process.

\begin{tabular}{|c|c|c|c|}
\hline \multirow{2}{*}{ Mixture } & \multicolumn{2}{|c|}{ Referred to leaching } & \multirow{2}{*}{$\begin{array}{c}\text { Referred to toxicity } \\
\text { EC }_{50} \\
(\mathrm{TU} /(\mathrm{kg} \text { sludge/l) })\end{array}$} \\
\hline & $\begin{array}{c}\text { Leached Cr } \\
\text { (mg/kg sludge) }\end{array}$ & $\begin{array}{c}\text { Retention of } \mathbf{C r} \\
(\%)\end{array}$ & \\
\hline M1-30-40 & 238.9 & 92.8 & 57.4 \\
\hline M1-40-10 & 194.7 & 94.1 & 740.7 \\
\hline M1-40-20 & 229.0 & 93.1 & 833.3 \\
\hline M1-40-30 & 250.3 & 92.5 & 72.2 \\
\hline M1-40-40 & 265.5 & 92.0 & 617.3 \\
\hline M1-40-50 & 270.8 & 91.8 & 555.6 \\
\hline M1-40-60 & 298.7 & 91.0 & 925.9 \\
\hline M1-50-40 & 302.7 & 90.9 & 350.9 \\
\hline M2-40-30 & 227.6 & 93.1 & 680.3 \\
\hline M2-40-40 & 225.7 & 93.2 & 123.5 \\
\hline M2-40-50 & 382.3 & 88.5 & 1111.1 \\
\hline M3-40-30 & 238.9 & 92.8 & 340.1 \\
\hline M3-40-40 & 252.2 & 92.4 & 111.1 \\
\hline M3-40-50 & 270.8 & 91.8 & 1666.7 \\
\hline
\end{tabular}

